\title{
At the origin of Italian Euroscepticism
}

\author{
Marco Brunazzo \\ University of Trento, Italy \\ marco.brunazzo@unitn.it \\ Bruno Mascitelli \\ Swinburne University of Technology, Melbourne \\ Bmascitelli@swin.edu.au
}

\begin{abstract}
The dominant narrative about the virtue of European integration is no longer the mantra of Italian politics. Alongside those parties who inherited the traditional 'Europhile' position, one can find parties whose support toward the EU is uncertain (like Forza Italia) or openly questioning the integration process (such as the Lega, Fratelli d'Italia and the Movimento 5 Stelle). Moreover, Euroscepticism in Italy reflects a deep change in the public opinion towards the EU: the consistent traditional support expressed by the Italians has of recent become more volatile and even critical. This article provides a brief look at changes in Italian positions on European integration, with a focus on the sentiments of both public opinion and the political elites, particularly after the Italy's entry into the Eurozone in 1998.
\end{abstract}

Keywords: Italy, Euroscepticism, Economic and Monetary Union, public opinion.

\section{Introduction}

The 2019 European Parliament (EP) elections demonstrated, if it were still necessary, how widespread Euroscepticism is in Italy. The most Eurosceptic party, the Lega Nord, led by Matteo Salvini, won 34\% of the vote in the Parliamentary elections. At the same

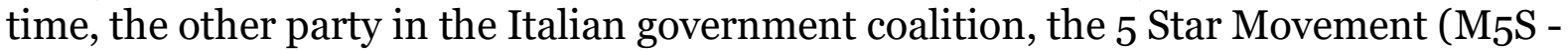
Movimento 5 Stelle), which also spoke loudly against the European Union (EU) and the Economic and Monetary Union (EMU), won $17.1 \%$ of the votes. If we add the $6.4 \%$ of votes received by the far-right nationalist party, Brothers of Italy (FdI - Fratelli d'Italia), we can see that the results of the 2019 EP elections were abundantly clear. Italians have decided to turn their backs on the EU. Contrary to what was occurring in other European countries, Eurosceptic parties in Italy achieved substantial electoral success.

EP elections in Italy are not necessarily second order elections, as they are often considered in other EU Member States (Pasquino and Valbruzzi, 2019). There is little doubt, and much evidence to suggest that Italian voters, if at all interested in the election, were more focused on national issues; and that political parties seemed to have little to say about Europe per sé (Chiaramonte et al., 2020). However, a closer 
examination of the 2019 election also provides evidence that something has changed in the political discourse about Europe in Italy. Italy's rock-solid support for the EU (and closer integration) is no longer the only (and, apparently, not the principal) narrative that defines the political discourse about Europe and thus the EP election campaign. European elections have confirmed how far Eurosceptic sentiments have gone, and how deep is the divide in broader public and elite opinion about Europe. Even if electoral volatility is particularly high in Italy (Landini \& Paparo, 2019), these elections show that the cohesive view of Europe that for a long-time characterised Italy, is no longer a feature of Italian politics.

The dominant post-war narrative of Europe in the Italian political discourse, and by consequence, European Parliament elections, was that Italy was firmly 'European'. European integration meant peace, prosperity, and political stability. Italy was not only one of the founding members, but also a frontrunner for a closer and deeper integration. As noted by Brunazzo and Della Sala, 'the European project was a source of 'salvation' for Italy, providing the path first to establish liberal democracy and to become a legitimate member of the European family of states; and then as the means to bring about economic and political modernization' (2011, p. 69).

However, since the mid-1990s, this single narrative has changed profoundly. Not only Italian citizens became much more critical toward EU integration, but also the political elites who adopted more instrumental views of the EU. As a consequence, a space for different interpretations and views on Italy's position on the European project was created, a space exploited by populist and Eurosceptic parties. The growing Euroscepticism needed a political entrepreneur to become a politically exploitable resource. Silvio Berlusconi, the founder of Forza Italia, was probably the first Italian political leader endorsing those sentiments. In other words, Italy is an interesting case study of a country in which the permissive consensus supporting EU integration has been substituted by constraining dissensus weakening EU integration (Hooghe \& Marks, 2008). According to most opinion polls, the multiple crises affecting the EU in the last decades (Fabbrini, 2019) has made the situation worse (Università di Siena / IAI, 2020).

The aim of this article is twofold. The first is to argue that the dominant narrative about the virtues of European integration is no longer the mantra of Italian politics. Party programs and public opinion toward the EU are nowadays much more differentiated than in the past. Alongside those parties who inherited the traditional 'Europhile' position (mainly, the Partito Democratico), we also find parties whose support of the EU is uncertain (like Forza Italia) or which are openly questioning the integration process (such as the Lega, Fratelli d'Italia and the Movimento 5 Stelle). The second aim of this article is to show that Euroscepticism in Italy reflects a deep change in the public opinion towards the EU. Particularly since the 1990s, many political parties and leaders have exploited the mistrust of Italian citizens toward the EU. In doing so, these parties have contributed to reinforce this Eurosceptical approach. Our discussion will be divided into two main sections. The first provides a brief look at changes in Italian positions on European integration, with a focus on the sentiments of both public opinion and the political elites during the so called First Italian Republic (1948-1994). In the second section we will look at the role of political actors (mainly parties and leaders) in the politicisation of Euroscepticism in Italy, particularly after Italy's entry into the Eurozone in 1998. 


\section{Italian Attitudes Towards the EU}

In a study published some 15 years ago, Sergio Fabbrini and Simona Piattoni (2007) tried to answer a fascinating question: has Italy been a pygmy or a giant in the history of the EU? Their research took into consideration the role Italy played in the adoption of several key EU policy decisions. They concluded that Italy was neither a pygmy nor a giant: Italy was the biggest of the pigmies or the smallest of the giants. There is little doubt the role played by Italy in the EU integration was somewhat erratic and strongly influenced by domestic politics. For this reason, the Italian participation in the EU integration can also be described as a 'rollercoaster journey' (Mascitelli \& Brunazzo, 2020).

After the end of the Second World War, the Italian political system was characterised by a deep cleavage between the Christian Democrats (DC) and the Communists (Fabbrini, 1998). The Italian Communist Party (PCI - Partito comunista italiano) was not strong enough to win electorally, but still able to influence Italian politics and government action. The DC and PCI represented two different worlds and had two opposite positions on foreign policy. The DC looked at the EU as the anchor for Italian democracy, while the PCI considered the EU the 'Trojan horse' of the USA in Western European politics (Brunazzo \& Della Sala, 2011). The Cold War, in other words, was not only a phenomenon influencing the international arena and the relations between Eastern and Western European States: in Italy it was one of the dynamics which shaped the domestic political system.

This is one of the reasons why Alcide De Gasperi, Italian Prime Minister between 1946 and 1953, supported all decisions anchoring Italy to Western liberal democracies, like joining NATO and supporting EU integration. The latter decision, in particular, offered De Gasperi the possibility to bring Italy back into the decision-making arenas of international politics allowing it to exit the 'minority group' to which it had been sentenced after its defeat in the Second World War. Moreover, for De Gasperi, EU integration and its closeness to the Marshall Plan offered an opportunity to rebuild Italy's economic system after the Second World War.

In contrast to the DC, the left in Italy was unequivocally opposed to EU integration. When the Treaty of Rome was presented in the Italian Parliament in 1957 it was passed only through the support of the Christian Democratic and the neo-fascist party Movimento Sociale Italiano. The Italian Communist Party (as occurred in France) voted against the Bill while the Italian Socialist Party abstained. The Italian Communist Party on the other hand saw both the Treaty of Rome and Euratom as having too much of a North Atlantic emphasis with a defined loss of national sovereignty. In a statement by the National leadership of the PCI, the judgement was categorical and in opposition. It said: 'The Common Market means less exports and less industrial production, layoffs and a lowering of living standards for the workers, and permission to the large private industries to dismantle State industries' (Steri, 2019, cited in Mascitelli \& Brunazzo, 2020, 43). Things changed only in the 1970s. Under the leadership of Enrico Berlinguer, the PCI decided to moderate its vision on EU integration and adopted the doctrine of Eurocommunism, which presented a more 'democratic and reformist form of communism'. In turn, the EU ceased to be an ideologically divisive issue. 
12(2)

Eurobarometer and other national and international surveys have consistently reported high levels of Italian support for the EU and European integration (Ammendola \& Isernia, 2005; Isernia, 2005; Conti et al., 2019). For a number of years, in particular during the 1970 os and the 1980s, the percentage of Italians who thought that Italian membership of the EU was a good thing was significantly higher than the average for all Member States (Figure 1). The same trend can be detected when looking at those responding to the statement, 'Taking everything into account... Italy has benefited from being a member of the EU' (Figure. 2).

Figure 1. Public opinion and membership in the EU (1973-2019) in percentage.

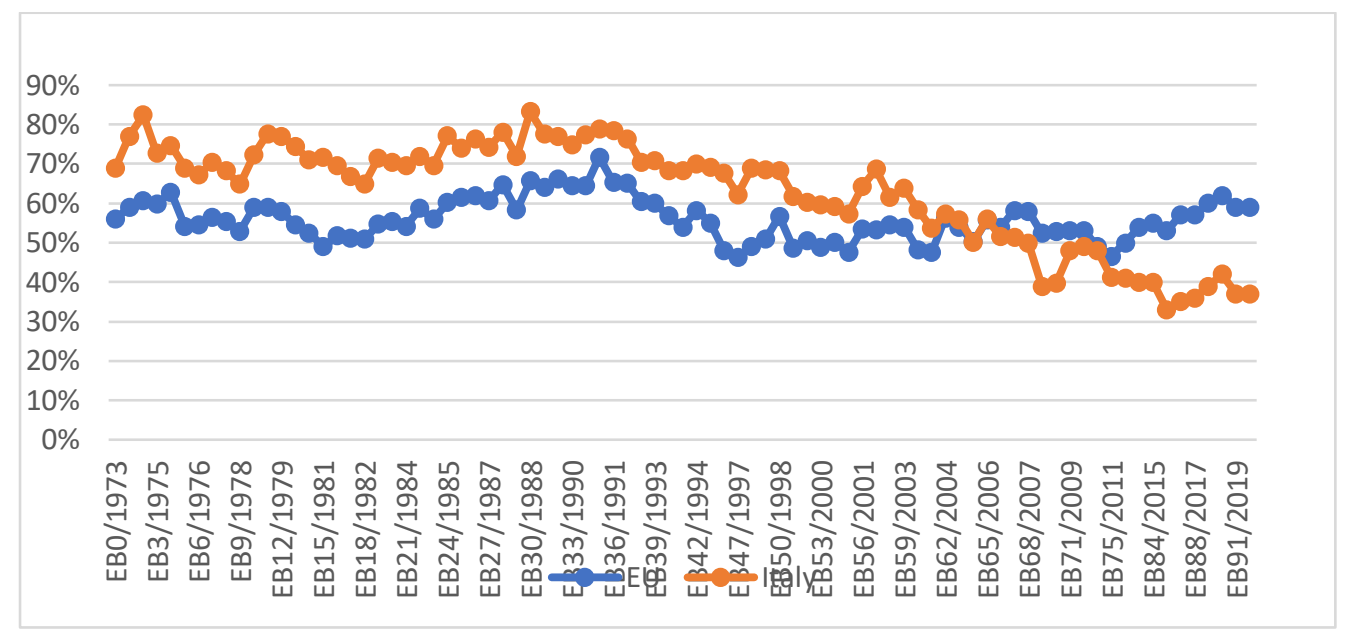

Question: Generally speaking, do you think that (OUR COUNTRY)'s membership of the EU is a good thing in \%? Source: Eurobarometers/Parlemeters, various years.

Figure 2. Public opinion and benefits from being a member of the EU (1983-2018) in percentage.

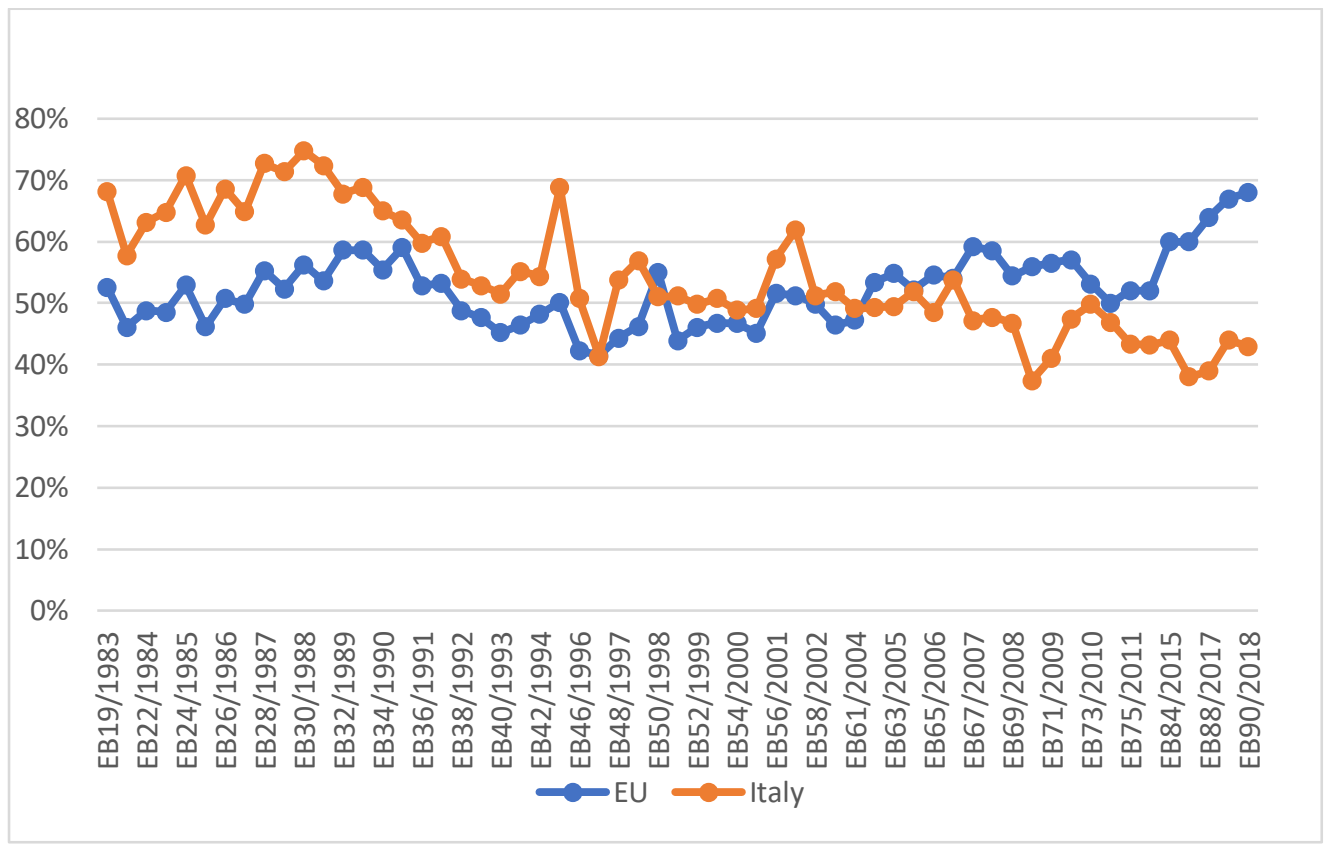

Question: Taking everything into account, would you say that (OUR COUNTRY) has on balance benefited or not from being a member of the EU?

Source: Eurobarometers/Parlemeters, various years. 
So, if, on the one hand, for long periods, Italy has been a 'Europhile' country, on the other, and more recently, things have changed. The consistent support expressed by Italians has of recent become more volatile and even critical towards EU integration. As a consequence, political elites could no longer take for granted the EU as a resource around which to mobilise political and electoral consensus and therefore party positions toward the EU integration have become more differentiated.

The decrease in support for the EU within Italian public opinion reflects developments within Italian politics and the party system since the end of the Cold War. When the central axis of post-war Italian politics - that is, the coalition of parties centred on the Christian Democracy that represented an anti-communist bulwark for democracy collapsed with the Berlin Wall, political preferences began to manifest greater variety and differentiation. This extended, over time, to views on Europe. Moreover, the growing differentiation of views on Europe has reflected the range of public and elite opinion on the need for reform and modernisation of economic, social and political institutions. Even after the end of the so-called First Republic, domestic politics still influence the European policy of the Italian governments (Conti, 2009).

The new party system inaugurated at the beginning of the 1990s saw greater differentiation within the centre-right with respect to Europe while the centre-left became even more committed to Europe and the idea that completing the process of economic, political and social modernisation could only come through Europe. However, party dynamics provide only a partial explanation. Hostility and indifference can be found within the centre-left as well. More importantly, some of the parties on the centre-right, such as the Lega Nord, had been strong supporters of the European Union at previous points in time (Brunazzo \& Gilbert, 2017).

Looking at domestic factors, Giuliani argues that the effective and idealistic Europeanism that characterised Italy for many decades had begun to give way to more materialist and utilitarian approaches (Giuliani, 2006). In the 1990s, the support for Europe started to include what many observers have identified as europeisti per disperazione (Europeanists out of desperation), that is those who are in favour of the EU mainly because they do not have confidence in Italian political institutions and in the national political class. As the citizens of the EU with the lowest level of confidence in national institutions and the highest level of confidence in the EU institutions, Italians have viewed the EU as an opportunity for change (Da Rin, 1999).

Another explanation may be found in the demands on macroeconomic policy that emerged with economic and monetary union in the Maastricht Treaty. The data presented above indicates that beginning in the late 1990s there was a precipitous decline in support for the EU at precisely the point at which it was embarking on its most ambitious project, the Economic and Monetary Union (EMU). In particular, the competitive pressures induced by the EU through the EMU and through enlargement with new Member States in 2004 created concerns among Italians (Bellucci \& Serricchio, 2012). As with all the states adopting the Euro, Italy has lost much of the scope for independent action in areas such as monetary policy and trade. The devaluation of the national currency used in the 1980 s to make Italian goods more competitive now became impossible. The enormity of state debt (used to finance generous public expenditure) became more pronounced. At the same time, from the 1990s, retrenchment policies had to be implemented to allow Italy to remain part of the Eurozone (Dyson \& Featherstone, 1996; Quaglia, 2004). At the same time, the 
enlargement to other EU countries - especially in Central and Eastern Europe induced many Italian entrepreneurs to delocalise production to other lower wage regions of the EU and outside the EU.

All this happened in a period of growing globalisation, with its consequences for Western societies. As Kriesi et al. (2008) have shown, globalisation and denationalisation have created a division between 'winners' and 'losers' in Western Europe. Though their study did not consider Italy, the case of Italy, their contribution can be usefully applied to Italy (Pellagata \& Visconti, 2018). Cultural issues such as mass immigration and resistance to European integration have acquired a new centrality in the political debate opening up new cleavages which have promoted party competition. The multiple crises of the EU have exacerbated this general trend.

The changes in Italian public opinion toward EU integration have domestic and external origins. In only a few years the Europhile Italy became a Eurosceptic country. During the 1990s, the political elites were too focused on the adoption of the necessary reforms to be part of the first group of countries joining the EMU. Once this goal had been achieved in 1998, Europe ceased to be considered a source of benefit and became a constraint.

\section{The 1990s: The rise of Italian Euroscepticism}

After decades of Italian involvement in the European project, at times with vigour and in other times with passive acceptance, the situation on the ground from the late $1990 \mathrm{os}$ onwards was destined to change. With Italy's formal acceptance of the Maastricht Treaty and more importantly, the criteria for acceptance and adherence to the single currency project, the ability to proceed with the European project without pain and sacrifice as experienced in the previous decades was coming to an end. Italy's engagement with further integration would involve deeper engagement of the country and especially its citizens, and this would involve high stakes and potentially economic pain to its businesses and its population.

In 1998 the European Commission announced the European Member States that met the Maastricht Criteria and therefore bound to become the founding members of the new single currency. While there was open concern and willingness to delay the date for the selection, given some nations were struggling with some of the criteria, this proposal was eventually quashed and the Member States that qualified were announced including Italy. At the time, the Governor of the Bank of Italy was Antonio Fazio, himself a pessimist on the question of Italy's preparedness for the single currency. Nonetheless, his concern was side-lined by the Italian government and Italy became one of the eleven Member States embarking on this historic journey. But there was concern beyond that of the Governor of the Bank of Italy. One observer noted:

'...Italy's top economists and finance officials were keen, indeed desperate, to join the eurozone. They subscribed to the vincolo esterno (external constraint) proposition. They insisted that lacking the escape valve of an ever-depreciating lira, Italy's political leaders would have no option but to enforce sound fiscal and structural policies to secure a better future for Italians. ... [EU scholars] say Mario Draghi... [then director general of the Italian treasury], 'believed in his soul' that the euro would enforce the discipline Italian governments needed' (Mody, 2018). 
It was common knowledge that in terms of government debt, Italy had far exceeded the $60 \%$ of government debt to GDP ratio stipulated by the Maastricht Criteria. Italy's public debt was closer to $120 \%$ of GDP - almost double than that indicated. But political expediency and credibility for the new Euro forced the European political elite to weigh up the impact of following through with strict adherence to the criteria and therefore missing out on the presence of certain nations. Italy was a beneficiary of this reasoning and was ultimately approved for the single currency despite not reaching the required government debt level (Marshall, 1999).

\section{The rise of Euroscepticism - Re-enter Silvio Berlusconi in 2001}

While Berlusconi surprisingly came briefly to government in March 1994, his real impact would occur almost a decade later. In 2001 Berlusconi entered government and drew key lines in the sand which would make his period of government a clear manifestation of open Euroscepticism not seen in Italian political circles since the end of the Second World War. Even before he assumed power, the European press was unforgiving of Berlusconi's political style and evident conflict of interest. The Economist as early as 2001 had a front cover with 'Fit to run Italy?'. It stated unequivocally:

'The known facts about Silvio Berlusconi, never mind the unanswered questions, rule him out for high office, even though his countrymen seem poised to make him Prime Minister' (The Economist, 2001).

This crusade by The Economist would last for a further decade and largely called out Berlusconi - holding him accountable more so than the Italian media did. The key events besides the emergence of the Centre-Right coalition would be the $2001 \mathrm{New}$ York Twin Towers attack and follow-up with military excursions into Afghanistan and later Iraq and the concrete arrival of the Single Currency in 2002. There was also e a personal side to this move away from Europe - Berlusconi not only got on well with Vladimir Putin, but he admired and liked George Bush and at the same time had little time for the Brussels bureaucracy. This contempt was most evident with the Berlusconi-Schultz confrontation in the European Parliament in July 2003 at the start of the Italian 6-month rotational Presidency of the European Union.

With his centre-right government, Berlusconi cobbled his way through the next decade and placed Italy on a course of a more critical appraisal of the EU leadership. Berlusconi's first flare up with the EU came rather quickly with Italy (on Berlusconi's orders) vetoing the European Commission proposal for a European arrest warrant for those suspected of financial crimes. This was interpreted by many as Berlusconi seeking to thwart any potential arrest warrants on himself (Mascitelli \& Brunazzo, 2020).

The main global development was the aftermath of the horrific attacks on the Twin Towers in New York. The Bush administration initially responded by attacking the Taliban in Afghanistan but soon shifted the blame onto to Iraq and the Saddam regime - a decision which divided most of the world and especially so in Europe. Berlusconi drew a line in the sand on the issue of the Twin Towers and the US response. He stated in an interview some years after: 'That was the date that changed world history forever' (Friedman, 2015, p. 117). 
Berlusconi joined the US forces in Iraq in June 2003 with the promise of 3,000 Italian troops while facing criticism from the Italian opposition and also from Italian citizens (Fisher, 2006). Joining the invasion of Iraq and the 'Coalition of the willing' also placed Italy at odds with France and Germany which were opposed to the war- an event which would remain an open wound throughout the first tenure of Berlusconi. Sergio Romano, one of the fathers of Italian diplomacy summarised the change in Italian foreign policy under Berlusconi:

'With the advent of Berlusconi, the picture [of foreign affairs] changed. In European and Atlantic relations, the leader of Forza Italia [Berlusconi's party in the centre-right coalition] showed little enthusiasm for the European Union and put relations with the United States at the top of his priorities' (Romano 2006, p. 102).

The arrival of the new liquid currency in January 2002, sparked some uncertainty regarding the real buying power Italians now had. As to the current assumed its place in everyday life, it would become evident that there was a perceived sense of less buying power compared to the Lira - a perception that the European Central Bank (ECB) and the EU denied and sought to counter with evidence and economic modelling. Berlusconi not only blamed the Brussels elite but also pointed the finger to the then President of the Commission and future political rival - Romano Prodi.

The Italian economy kept being a poor performer from the beginning of the Berlusconi mandate in 2001 until its closure in 2006. Moreover, Italy's experience of using its currency to counter poor performances through currency devaluation was no longer possible due to the Economic Monetary Union which placed control of the currency in the hands of the ECB. Italy started to hurt from this new scenario. Italy's finance minister under Berlusconi noted this new state of affairs indicating:

'Italy is in a difficult transition period from one regime to another. There used to be high inflation, frequent devaluations, a high deficit and high debt. From 1998, it moved in the opposite direction. It moved from one kind of metabolism to another. The old one was unsustainable, and we are paying the price, changing 30 years of habits. It's a painful struggle' (Barber, 2005).

Throughout the 2001-2006 Berlusconi government, numerous attacks on the EU and the Euro were made often by the Berlusconi allies but with the clear approval of the Prime Minister. These antics were demonstrated through the proposal of a referendum to exit the Euro coming from the Lega (Berlusconi's coalition ally). Then came Berlusconi's own admission when he blamed Prodi and Brussels for placing Italy in this situation and for agreeing on Italy's entrance into the Eurozone at too high an exchange rate. His final comment was: 'Prodi's euro conned us all' (Barber, 2005).

In 2004 the European parliamentary elections took place and Berlusconi suffered a significant defeat to the centre-left opposition headed by Romano Prodi. Having just relinquished his presidency of the European Commission in 2004, Prodi was bound for re-entry into Italian politics and Berlusconi's main rival. While EP results are not generally credited with much significance, it was an indication of what was to come, and the centre left prepared itself to govern at the next possible moment.

\section{The short departure of Berlusconi - Romano Prodi takes over}


In 2006 the Berlusconi centre-right coalition lost the election to Romano Prodi and his unruly centre-left conglomeration of some 16 parties. The loss was so slim it was a matter of a handful of votes. The new government had to contend with a range of urgent matters including the need for a new President of the Republic. The government installed Giorgio Napolitano at the age of 80 and the first former Communist to assume that position of President. But equally controversial was the centre-left commitment to withdraw troops from Iraq where Italy had contributed the third highest number of troops. Prodi had declared the invasion of Iraq a 'grave mistake' and 'an occupation' and his pledge was to withdraw the troops as soon as possible (Sturcke, 2006). This caused some tensions with George Bush but equally created some greater level of cooperation with the European partners, primarily France and Germany.

However, the centre left hold on power was short lived and fraught with uncertainty and factionalism as could be expected with such a large and volatile coalition. The coalition fell apart with multiple resignations and a complete collapse of the centre left. It was back to the polls in 2008 and this time Berlusconi's centre right coalition won convincingly with a working majority in both houses. Despite this potential political capital, the next three years (2008-2011) would see Berlusconi as one observer noted: 'From 2008 onward, we saw the sexual excesses and 'planetary' gaffes that would make Berlusconi a household name around the world - and mark his irreversible decline as a political force' (Day, 2015, p. 112).

The beginning of his return to power however coincided with the dramatic spread of the global financial crisis (GFC) and its European variant. This more than any aspect of his corruption, sleaze, and self-serving approach would be his undoing and brought him into direct confrontation with his base - the business community and the stock markets. The European GFC was especially punishing on those economies which had high budget deficits, high public debt to GDP and were experiencing low or negative economic growth - this was Italy. But Italy had a more damning feature - Berlusconi as its prime minister.

The crisis - with little or no stimulus offered by the Italian government - would demonstrate Italy to be one of the weak links within the Eurozone. While the Greek Crisis was capturing most of the attention, there were greater fears for the failure of Italy to repay its borrowing costs as the markets were seeing Italy as a major risk - not only because of a failed economy - it suffered a 6\% decline in GDP growth - but also and primarily due to the presence of Berlusconi as its Prime Minister. The failure of Italy would have devastating effects on the Eurozone and could have seriously damaged the financial framework of the Eurozone.

Berlusconi's leadership was beginning to disturb other European leaders and the fear that an unravelling Italian economy could reverberate on the European economies was beginning to make many nervous. Italy's public debt was higher than the economies of Ireland, Portugal and Greece combined. Merkel was forthright in her call for Berlusconi's replacement as soon as possible (Fusaro, 2012, p. 86). However, the stock and financial markets in Italy were seeing to that!

In 2011 Berlusconi's allies were beginning to abandon him. In November 2011, Berlusconi found himself in a minority government and was forced to step down. The President, required to bring some order to situations like this, lost no time and sought 
out a 'technical' replacement to Berlusconi. The purpose of this was to bring calm to the markets, restore some credibility with Brussels, and bring a rapid solution to mismanagement of the country. The choice was Mario Monti who was well known in Italian business circles, but especially in Brussels, having been the EU Commissioner for Competition, with a reputation of being a firm and committed Europeanist. Monti quickly assembled a government and went about 'reforming' the Italian economy in the only way he knew - austerity and more austerity. This was music to the ears of Brussels but did little good to an already damaged economy. This would be a mistake which Monti would pay for in the 2013 election after barely 14 months in government.

In the meantime, after years of Berlusconi neglect and negativity towards the European Union, and then the Monti austerity program in the name of the European Union, trust in the EU in Italy, a onetime Europhile nation, began to turn towards Euroscepticism. According to one study, between 2000 and 2012, Italian trust in the European Union declined from $56 \%$ to $36 \%$ (Demos \& Pi, 2012). This was a qualitative change in the Italian sense of support and trust in the EU and one that was without precedent.

\section{The growing concern about migration}

For the following five years, the Democratic Party directed the affairs of the country and gave the EU an ongoing friend in Rome. However, the post Arab Spring consequences were not being taken into consideration: the fall of Gaddafi, collapse of Libya, and especially the fallout of the Syrian civil war. All these provided the recipe for a major exodus from these war-torn countries. Italy was in the front line to receive them.

Throughout the 2013-15 period, thousands of refugees and migrants took their chances trying to reach Europe by sea and many through Italy. Italy was not their ultimate destination, but it was often their entry point. Italy felt overwhelmed, especially many of the poorer areas of the south which had to deal with the incoming migrant streams, processing them through rundown reception centres and inhospitable migrant welcome centres. Asking for help from the EU through various schemes such as Frontex was the formal procedure, but official Italy saw that the EU was unresponsive. To the unofficial Italy, this seemed like being left alone and betrayed. The Democratic Party kept the lines of communication with the Member States and Brussels informed, but there seemed to be paralysis and deafness. None of this was missed by Italians which unfortunately put the migration question on the map of discord with the EU in the years that followed.

\section{Enter the anti-EU government}

The ambitious Matteo Renzi at the helm of the PD and the Italian government, lost favour when his constitutional referendum turned out to be a miscalculation and was defeated in late 2016. The government plodded along for a further year or so and in March 2018 went again to the polls. The result from this election would be seismic. There was no majority in a three way contest and the two top contenders were the 5 Star Movement and the Lega - two political contenders that had very little in common except their dislike for the European Union, with threats to leave the Euro and even the European Union. Though barely possible to contemplate, the two political 
formations managed to cobble a government together with an 'independent' prime minister Giuseppe Conte.

From June until August 2019, the government went from one dispute with the EU to another with most of the fire coming from Matteo Salvini and his hostility to migration and refusal to align himself with any of the EU migration policies and approaches. Salvini closed the Italian ports, fought with Non-Government Organisations (NGOs) to stop saving migrants crossing the sea, and forced ships with migrants on board to berth in other countries. The 5 Star Movement was equally busy with spending programs which had little sustainability attached to them, and certainly insufficient revenue sources. The meetings with the EU were often inconclusive and tense. Poor communication had returned between Rome and Brussels.

This impasse came to a close with the crisis of the 5 Star Movement - Lega government in August 2019 and in another most unlikely coalition - the 5 Star Movement, with no other option, engaged in an alliance with the Democratic Party. Keeping Giuseppe Conte as Prime Minister, this coalition was considered one of national salvation - or better still, salvation of both parties until they need to face the ballot box. Again, at the centre of the tension, was the approach towards the EU.

\section{Then came Covid 19}

Only months after this new government came into being, Italy faced the effects of the Corona virus pandemic. Italy was hit early and hard and, for some time, had the most infections and the most deaths in the world (Villa 2020). The health system was on its last legs and the country was in lockdown. The economic effects have been disastrous and ironically centred on Italy's economic engine location - the north.

What was least expected were the difficulties within the EU and between the Member States: access to personal protective equipment (PPE), no coordination between Member States, even outright border closure between Member States, and then of course the complete failure of the EU to support a fellow Member State (Università di Siena / IAI, 2020). Within Italy this failure by the EU was not lost on those who expected more and had faith in the EU. There was a real sense of betrayal. In the EU, the President of the Commission realised the error and made 'a heartfelt apology to Italy' (D'Argenio, 2020). For many, it was too little too late.

\section{Conclusion}

The journey taken by Italy from being a Europhile Member State of the European Union to a Eurosceptic is not a surprising one. The heavy commitments and sacrifices Italy initially signed on to join its fellow members in the ambitious project of European integration, stretched its abilities to do so, especially Maastricht and the Single Currency project. This was a difficult step but not an impossible one. What made it more difficult was the impact of the global financial crisis in the 2000s with long lasting damage to Italy. Equally, this economic fragility exposed the limits of the sacrifice and showed that wishing away the lead weight of public debt within the confines of the Economic and Monetary Union would not be either simple or short in duration.' 
What ultimately sealed Italy's fate in its transition to Eurosceptic was the new political direction chartered by the centre right leadership, and Berlusconi specifically in openly challenging the leadership of Brussels and taking sides with the US on war. It was compounded by the disarray and uncoordinated response to migration across the Mediterranean and Italy's inability to process this exodus on its own - as it felt on its own and without the EU behind it. This was further compounded by the tragic impact of the Corona virus pandemic Italy and, again, by a failure of EU solidarity. The Eurosceptic political direction was built on a changed economic and social landscape that was pushing many Italians to question the viability and value of being part of the EU - something they had never had to face before in the long 70 year history of Italian involvement in the European project. Whether Italy will keep distancing itself from the EU is difficult to tell but the political elite in Brussels has quite some catching up to do.

\section{References}

Amendola, T., \& Isernia, P. (2005). L'Europa vista dagli italiani: i primi vent'anni. In M. Cotta, M. Isernia, P. \& Verzichelli, L. (Eds.). L'Europa in Italia: Elite, opinione pubblica e decisioni (pp. 117-170). Il Mulino.

Barber, T. (2005, July 29). Italy: Comment and analysis. The Financial Times.

Bellucci, P. \& Serricchio, F. (2012), Cosa pensano i cittadini dell'Europa. In Bellucci, P. \& Conti, N. (Eds.). Gli italiani e l'Europa (pp. 135-156). Carocci.

Brunazzo, M. \& Della Sala, V. (2011). From salvation to pragmatic indifference? Europe in Italian political discourse. In Harmsen, R., \& Schild, J. (Eds.). Debating Europe: The 2009 European Parliament elections and beyond (pp. 69-84). Nomos.

Brunazzo, M. \& Gilbert, M. (2017). Insurgents against Brussels: Euroscepticism and the right-wing populist turn of the Lega Nord since 2013. Journal of Modern Italian Studies, 22(5), 624-641. https://doi.org/10.1080/1354571X.2017.1389524

Chiaramonte A., De Sio L., \& Emanuele V. (2020). Salvini's success and the collapse of the Five-star Movement: The European elections of 2019. Contemporary Italian Politics, 12(2), 140-154. https://doi.org/10.1080/23248823.2020.1743475

Conti, N. (2009). L'Europa vista dai partiti: Paesi dell'UE e Italia a confronto, Pisa University Press.

Conti, N., Marangoni, F. \& Verzichelli, L. (2020). Euroscepticism in Italy from the onset of the crisis: Tired of Europe?. Southern European Society and Politics. https://doi.org/10.1080/13608746.2020.1757885

D’Argenio, A. (2020, April, 16). Coronavirus, Von der Leyen: 'La Ue deve scusarsi con l'Italia'. Di Maio: 'Atto di verità'. La Repubblica. https://www.repubblica.it/esteri/2020/04/16/news/coronavirus von der leyen s entite scuse all italia ora l ue c e $-254161800 /$

Da Rin, R. (1999, April 10). Italiani europeisti per disperazione. Il Sole 24 Ore.

Day, M. (2015). Being Berlusconi: the rise and fall from cosa nostra to bunga bunga. Nero Publishers.

Demos \& Pi (2012). Altre ricerche - La fiducia degli italiani nell'Europa unita. 
Dyson, K. \& Featherstone, K. (1996). Italy and the EMU as a 'vincolo esterno': Empowering the technocrats, transforming the state. Southern European Society and Politics, 1(2), 272-299. https://doi.org/10.1080/13608749608539475

Fabbrini, S. (2019). Europe's future: Decoupling and reforming. Cambridge University Press.

Fabbrini, S. and Piattoni, S. (Eds.) (2007). Italy in the European Union. Redefining national interest in a compound polity. Rowman and Littlefield.

Fisher, I. (2006, May 19). Italy calls Iraq War 'grave error'. New York Times. https://www.nytimes.com/2006/05/19/world/europe/19italy.html

Friedman, A. (2015). Berlusconi: The epic story of a billionaire who took over Italy. Hachette Books.

Fusaro, C. (2012). La formazione del governo Monti, e il ruolo del Presidente della Repubblica. In Bosco, A. \& McDonnell, D. (Eds.). Politica in Italia: I fatti dell'anno e le interpretazioni (pp. 83-100). Il Mulino.

Giuliani, M. (2006). La politica europea. Il Mulino.

Hooghe, L., \& Marks, G. (2009). A postfunctionalist theory of European integration: From permissive consensus to constraining dissensus. British Journal of Political Science, 39(1), 1-23. https://doi.org/10.1017/Soo07123408000409

Isernia, P. (2005). L'Europa vista dagli italiani: vent'anni dopo. In M. Cotta, M. Isernia, P. \&

Verzichelli, L. (Eds.). L'Europa in Italia: Elite, opinione pubblica e decisioni (pp. 223-276). Il Mulino.

Kriesi, H., Grande, E., Lachat, E., Dolezal, M. Bornschier, S. \& Frey, Th. (2008). West European politics in the age of globalization. Cambridge University Press.

Landini, I. \& Paparo, A. (2019). Italy: Complete overturn among government partners: League doubled, M5S halved. In De Sio, L., Franklin, M.N. \& Russo, L. (Eds.). The European Parliament elections of 2019 (pp. 173-179). Luiss University Press.

Marshall, M. (1999). The Bank: Birth of Europe's Central Bank \& rebirth of Europe's power. Random House.

Mascitelli, B. \& Brunazzo, M. (2020). Italy and the European Union: A rollercoaster journey. Nova Publishers.

Mody, A. (2018, June 12). Opinion: Italy never should have joined the euro, and the ECB can't rescue it from its next crisis. Wall Street Journal Market Watch. https://www.marketwatch.-com/story/italy-never-should-have-joined-the-euro-andthe-ecb-cant-rescue-it-from-its-next-crisis-2018-06-11

O'Leary, N. (2017, December 19). How Italy turned Eurosceptic: Crisis generation prepares to vote for the first time. Politico. https://www.politico.eu/article/italy-euroskepticsurge-migration-crisis-eu/

Pasquino, G. \& Valbruzzi, M. (2019). The 2019 European elections: A 'second-order' vote with 'first-order' effects. Journal of Modern Italian Studies, 24(5), 736-756. https://doi.org/10.1080/1354571X.2019.1681706 
12(2)

Pellegata, A. \& Visconti, F. (2018, June 19). The winners and losers of globalisation in the Italian elections. EUvision. http://www.euvisions.eu/winners-globalisationelections/

Quaglia, L. (2004). Italy's policy toward European monetary integration: bringing ideas back in? Journal of European Public Policy, 11(6). 1096-1111. https://doi.org/10.1080/1350176042000298129

Romano S. (2006). Berlusconi's foreign policy: Inverting traditional priorities. The International Spectator, 41(2), 101-107. https://doi.org/10.1080/03932720608459419

Steri, B. (2019, March 31), Il PCI di Togliatti contro l'europeismo: Un libro documentato e coraggioso. Marx XXI. http://www.marx21.it/index.php/internazionale/europa/29653-il-pci-di-togliatti-contro-leuropeismo-un-librodocumentato-e-coraggioso

Sturcke, J. (2006, May 19). Prodi condemns Iraq war as 'grave mistake'. The Guardian.

The Economist (2001, April 26). Fit to run Italy?. The Economist.

Università di Siena / IAI (2020). Emergenza coronavirus e politica estera. L'opinione degli italiani sul governo, l'Europa e la cooperazione internazionale. Affari internazionali. https://www.affarinternazionali.it/wp-content/uploads/2020/05/LAPSIAI 2020 covid.pdf

Villa, M. (2020, March 27). Covid-19 and Italy's case fatality rate: What's the catch?, ISPI Analysis. https://www.ispionline.it/en/publication/covid-19-and-italys-case-fatalityrate-whats-catch-25.586 
Copyright of Australian \& New Zealand Journal of European Studies is the property of Contemporary European Studies Association of Australia (CESAA) and its content may not be copied or emailed to multiple sites or posted to a listserv without the copyright holder's express written permission. However, users may print, download, or email articles for individual use. 